\title{
Financial Support Problems of Developing a Territory`s Touristic Potential
}

\author{
Natalia Kataeva $^{1,2,{ }^{*}}$, Irina Marakulina ${ }^{1}$, Yelena Snigireva $^{1}$ and Sergey Barinov ${ }^{3}$ \\ ${ }^{1}$ Vyatka State Agricultural Academy, October Avenue, 133, Kirov, 610017, Russia \\ ${ }^{2}$ Vyatka State University, Moskovskaya 36, Kirov, 610000, Russia \\ ${ }^{3}$ Moscow State University of Civil Engineering, 129337, 26, Yaroslavskoye Shosse, Moscow, Russia
}

\begin{abstract}
This article considers the influence of financial support on developing the territory`s touristic potential. Having applied economicmathematical and statistical methods, the authors have analyzed the touristic and investment potential of Kirov region. They have come to the conclusion that the financing of developing the territory's touristic and investment potential is performed mainly using the federal and regional budget funds within the framework of the approved Development Strategy of Territories, the share of private investment is rather small. Using the methods of logical qualitative judgments and scientific assessment on the basis of the existing Program for Tourism Development Program in Kirov region, the authors have offered a two-stage innovative scenario for developing the territory. This scenario relies on the available resource base and its development prospects on account of additional financing. Attracting additional investments in developing the touristic potential of Kirov region is possible due to the image promotion of the region, the popularization and enhancement of the status of events held on its territory, as well as the development of infrastructure facilities. In our opinion, the possibility to invest in developing infrastructure facilities is of prime importance as infrastructure facilities greatly affect the increase in tourist flow of the region.
\end{abstract}

\section{Introduction}

Nowadays under complex economic and political situation in the world, accompanied by introduced sanctions, the role and importance of developing domestic tourism in Russia is growing strongly. This is primarily connected with the fact that Russia as a tourist attraction has significantly increased its force of attraction in the Travel and Tourism Competitiveness Index (hereinafter referred to as TTCI). This Index is produced by the experts from the World Economic Forum and the Strategy Partners Group.

Touristic potential studies have shown [1] that in the tourism and travel sector Russia ranks 23rd with the TTCI index being 3.55 (here natural resources and cultural heritage are evaluated). The purpose of this study was to examine the Russian tourism market and to determine financial support sources for developing territories. The desire to increase the tourist flow determines the need of solving many problems of the tourism sector. The most important of them are: understanding and evaluating the touristic potential of the tourist 
attraction, identifying investment sources for developing the territory, selecting markets where the object in question has a competitive advantage, motivating tourists travel and at last promoting tourist products.

Russian scientists in the field of regional economy N. V. Zubarevich [2], R. A. Popov [3], G. G. Fetisov [4] examine the theoretical and methodological foundations and approaches to studying the process of functioning and developing socio-economic systems and they analyze the trends in forming effective reproductive relationships within a regional socio-economic system. Features of sustainable socio-economic development of regions, as well as the problems of identifying its reserves have been investigated in the works of domestic and foreign scientists: A. G. Granberg [5], V. N. Leksin [6], A. Ya. Livshits [7], T. Peters, R. Waterman [8]. The problems of managing the regional economy, the evaluation and use of regional resources are considered in the works of such scientists as $\mathrm{V}$. N. Afanasyev [9], I. A. Boyko [10], A. L. Gaponenko [11], S. Yu. Glazyev [12], Yu. S. Dulshikov [13], I. P. Ivanitskaya [14]. The following well-known Russian researchers I. M. Aleksandrov [15], A. V. Gukova, N. E. Yegorova examine and describe the theoretical basis of efficiency increase in elements interaction of socio-economic systems in the process of their development and the ways to solve current and recurring problems that destabilize the work of the socio-economic systems. For our research it was also of high importance to study the works devoted to the problems of developing the regional economy. One of them is the work of A. S. Novoselov, who paid special attention to the financial system role in this process.

At the same time the problems connected with the very process of forming the financial support for developing the regional economy and the peculiarities of individual constituent elements functioning of this system haven't been sufficiently studied. The directions of improving the use of such financial support mechanisms for developing the regional economy as different types of attracting investments in developing the touristic potential of the territory have not been sufficiently examined.

\section{Methods}

The theoretical and methodological base of our work was the conceptual research of developing the regional socioeconomic system, the reproductive interrelations between its elements (subsystems) based on the use of the innovative approach in order to create a regional competitive economy. And also our theoretical and methodological base included studies in the field of regional economy and management on the basis of economicmathematical and statistical methods of modeling and forecasting, which are presented in the domestic and foreign scientific literature.

Justification and explication of the work key takeaways connected with the proposed recommendations was performed with the use of traditional methods of deduction and induction, structural and functional analysis, qualitative judgment and estimates, system and complex approaches and the subsequent prognostic synthesis of the obtained data. The empirical part of the work is based on applying mathematical and statistical methods of data analysis and extrapolation projection.

\section{Results}

During the study we have examined the main trends of the Russian tourism market, the domestic tourism market on the information of Kirov region. And we have also analyzed the existing strategy of developing the territory`s touristic potential and the financing sources used in realizing this strategy. 
The main area of our research is Kirov region, which was founded on December 5, 1936. The total area of Kirov region is 120374 square kilometers, it is located in the European part of Russia, to the north-east from the center. According to the data of 2016, the population of the region is 1297 thousand people, $75.9 \%$ of the population is urban. The ethnic composition of the region is mostly represented by Russians, but in addition, the representatives of such nationalities as Udmurt, Mari, Tatars, Komi and others also live in the region. Kirov region is a part of Volga Federal District.

Kirov region is really a unique region that borders on 9 subjects of the Russian Federation and it is located on the border of Urals and Volga region and the Russian North. Kirov region includes 18 cities, the largest ones of which are Kirov, Kirovo-Chepetsk, Vyatskie Polyany, Kotelnich, Slobodskoy, Yaransk, Omutninsk. The administrative center is the city of Kirov, which was called Khlynov until 1781, and it was called Vyatka until 1934. The population of the city of Kirov is 496,986 people. The city is located $896 \mathrm{~km}$ from the capital of the Russian Federation and it is located in one time zone with Moscow. The administrative division of the Kirov region also includes 39 municipal districts.

The touristic potential of Kirov region is one of the constituent parts of the region's economic potential as a whole. Economic potential is a general expression of qualitative changes in social production. The region's economic potential includes geographical / natural-resource facilities, labour resources, production, financial, foreign economic and scientific and technical facilities. According to this methodology, it is possible to determine the region's touristic potential as an opportunity for tourism resources located on the territory of the region to bring profits for economic subjects. The touristic potential, as a part of the region's economic potential, includes the natural-resource facilities; historical and cultural facilities; recreational facilities; transport infrastructure; accommodation facilities; financial (investment) facilities. During the study, we have made a hypothesis on the influence of financing the territory`s development as an object of domestic tourism on the formation of this territory image and the increase in the tourist flow. For an adequate financial support for developing the territories touristic potential, investments are needed. To attract investments, the territory must possess a good investment potential.

The territory's investment potential is defined by us as a set of factors determining the risks level that arise when realizing investment projects on a given territory and also determining the possibility of these projects payback and making profit. In other words, it means the territory's force of attraction for an investor, the sufficiency of conditions for opening and developing a business.

The whole set of factors that make up the investment potential can be divided into two groups: fixed factors and variable factors.

Fixed factors include:

- geographical location of the territory (convenience of the territory location, free access to the main markets, transport routes and resources);

- the availability of natural resources.

To be exact, these are the factors that we should take into account. They can be both highly favorable and unfavorable.

As for variable factors it's possible to change them, but they are different in terms of implementing such changes. In this regard, we offer to subdivide the variable factors into two groups:

- variable factors, that can be changed in the long-run. The examples of them are transport and technical infrastructure of the territory (roads, ports, airports, gas and oil pipelines, power lines, communication facilities, treatment works) and social, political and environmental situations, as well as the intellectual potential of the territory (labour force qualification, availability of innovative centers); 
- variable factors, that can be changed in the short-run. These factors include local legislation (the system of normative legal acts regulating investment activity on the municipal entity territory) and the authorities policy and management with respect to investors (for example, creating a system for developing and supporting business).

Thus, it is possible to change the total investment potential of the territory by influencing the variable factors. Moreover, unfavorable fixed factors do not mean that the territory can not become a positive investment territory. The investment attractiveness doesn 't depend on the value of fixed factors if the variable factors are improved.

Consequently, the investment policy of the municipal entity should be based on the methods of influencing the variable factors.

The specific components of the touristic potential financial support are:

1) state subsidies;

2) money of consumers that are willing to pay for provided tourist services;

3) investors' funds that should be spent on:

- completing the construction of tourist attractions, as well as reconstruction and modernization of operating enterprises of the complex;

- constructing infrastructure facilities, recreation and entertainment industry facilities;

- developing and applying new technologies for the use of tourism resources;

- implementing measures aimed at improving the service for tourists, improving the quality of services provided to them [20].

The main sources of financing the municipal target program "Creating conditions for the tourism development on the territory of the municipal entity "The City of Kirov" for 2012-2015" (Fig. 1) are the local funds. The minimum amount of funding from extrabudgetary sources is due to the low investment attractiveness of Kirov region for potential sponsors and investors.

$\equiv$ Local Budget $\equiv$ Extrabudgetary Sources

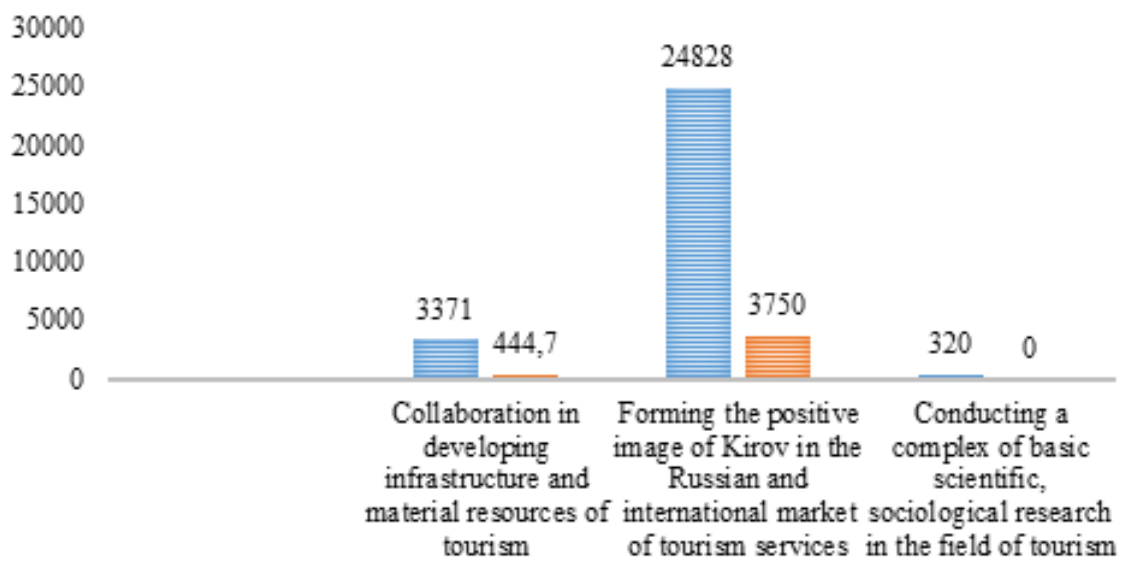

Fig. 1. The sources of financing the municipal target program "Creating conditions for the tourism development on the territory of the municipal entity "The City of Kirov" for 2012-2015"

Developing and implementing the development strategy of Kirov region as a domestic tourism object is performed on the basis of available touristic potential, taking into account the financial capacities of the region which depend on the region's natural and climatic, cultural and economic characteristics. This process contributes to improving the quality of life of the population and the investment attractiveness of the region.

The current situation in the tourist services market points to the fact that in Kirov region the tourist infrastructure and the region`s image aren`t developed enough and there is a lack 
of information about tourist attractions located on the territory of the region. This fact also proves the need to develop and strengthen an elaborate image-building policy in order to increase the investment attractiveness of the territory.

Table 1. The Evaluation of Kirov Region as a Domestic Tourism Object.

\begin{tabular}{|l|l|l|l|}
\hline \multicolumn{2}{|l|}{ Indicators } & Observed Trend & $\begin{array}{l}\text { Competitive } \\
\text { Position }\end{array}$ \\
\hline $\begin{array}{l}\text { Full-year income (in } \\
2016)\end{array}$ & 2 billion rubles & Decrease & $\begin{array}{l}\text { Weak } \\
\text { Worsening }\end{array}$ \\
\hline $\begin{array}{l}\text { The volume of sales } \\
\text { (in 2016) }\end{array}$ & $\begin{array}{l}\text { Number of tourists } \\
\text { Income from tourist } \\
\text { products sales }\end{array}$ & $\begin{array}{l}\text { About 300 thousand } \\
\text { people } \\
111,5 \text { mln. rub. }\end{array}$ & Worsening \\
\hline $\begin{array}{l}\text { Market share } \\
\text { in 2016) }\end{array}$ & $\begin{array}{l}\text { Total market share } \\
\text { according to the income } \\
\text { from tourism in Volga } \\
\text { Federal District, in } \\
\text { percent, \% }\end{array}$ & $\begin{array}{l}3,5 \% \\
\text { Outsider }\end{array}$ & Worsening \\
\hline Positioning & $\begin{array}{l}\text { From the competitors } \\
\text { point of view }\end{array}$ & $\begin{array}{l}\text { According to the } \\
\text { ranking, Kirov region } \\
\text { as a tourist attraction } \\
\text { is second to the last }\end{array}$ & Weak position \\
Volume business & Weak position \\
\hline Market segment & Occupied segments & Not carried out & Weak position \\
\hline $\begin{array}{l}\text { Degree of customer } \\
\text { satisfaction }\end{array}$ & $\begin{array}{l}\text { Research of customer } \\
\text { satisfaction }\end{array}$ & $\begin{array}{l}\text { Performance index: } \\
\text { The situation is worsening, the market share is decreasing and, accordingly, the volume of } \\
\text { incomes from the tourist products sales is also decreasing. }\end{array}$ \\
\hline
\end{tabular}

The urgency of developing and adopting the next Program for the tourism development in Kirov region for 2017 - 2020 is determined by the need to continue the set of measures in order to create a competitive tourism industry and to achieve the target indicators values of the Development Strategy of Kirov Region until 2020 (which is approved by the Kirov Region Government on August 12, 2008 (No. 142/319)) and the Kirov Region Program "Culture Development" for 2013 - 2020. According to the Development Strategy of Kirov region until 2020 and the program for culture development, the tourism industry is one of the strategic and promising direction of social and economic development of the region. And to be exact, tourism is assigned to the second group of sectoral priorities and it is one of the basic sectors of Kirov region economy.

The main directions of developing the domestic and inbound tourism of Kirov region in 2017 are presented in Table 2.

Table 2. The main directions of developing the domestic and inbound tourism of Kirov region.

\begin{tabular}{|l|l|}
\hline \multicolumn{1}{|c|}{ Indicators } & \multicolumn{1}{c|}{ Value } \\
\hline $\begin{array}{l}\text { Number of tour operators and travel } \\
\text { agencies }\end{array}$ & $\begin{array}{l}153,14 \text { tour operators are included in a } \\
\text { single federal register }\end{array}$ \\
\hline Hotels in the region & $\begin{array}{l}\text { Over } 70 \text { objects. The guest room stock is } \\
7000 \text { rooms. }\end{array}$ \\
\hline Holiday resorts and health centers & Over 20 objects \\
\hline $\begin{array}{l}\text { The volume of paid services provided by } \\
\text { the tourism industry objects (in 2016) }\end{array}$ & 2 billion rubles \\
\hline $\begin{array}{l}\text { The volume of tax deductions to all } \\
\text { levels budgets (in 2016) }\end{array}$ & 111,5 million rubles \\
\hline
\end{tabular}


In the region interaction in the sphere of tourism is the following: Center for Tourism Development - Vyatka Chamber of Trade and Industry (CTI) - Center for Children and Youth Tourism and Excursions - Federation of Sport and Health Tourism - Universities Municipal Entities - Executive Authorities - Ministry

The activities and financial costs for supporting and developing the domestic and inbound tourism of Kirov region in 2017 are presented in Table 3.

Table 3. Supporting and developing the domestic and inbound tourism of Kirov region.

\begin{tabular}{|l|c|}
\hline \multicolumn{1}{|c|}{ Indicators } & Value \\
\hline Total number of events & 23 \\
\hline Total funding, in rubles. & 12126000 \\
\hline Volume of financing from the federal budget, in rubles. & 5000000 \\
\hline Volume of financing from the regional budget, in rubles. & 7126000 \\
\hline
\end{tabular}

To promote the touristic potential of Kirov region in 2017, the following events were hold: participation in international exhibitions, organizing special days of Kirov region in other regions of Russia; development of information tours and various competitions in order to evaluate people`s knowledge of the region`s touristic potential; participation in federal projects; organization of event tourism actions; conducting seminars on tourism development; coordination of the municipal entities activities in the field of tourism; cooperation with Kirov tour operators; participation in all-Russian competitions / festivals / awards.

\section{Discussion}

According to the data about other regions of the Russian Federation, nowadays 65 regional tourism development programs are realized and they are developed in the regions, in particular the concepts of tourism development have been adopted in 5 regions of Russia. Among the most effective working programs are the republics of Tatarstan and Bashkiria, and the program for tourism development in Tyumen region (which pay special attention to creating a tourist resort area in Tobolsk).

Special attention in developing a new program for tourism development in Kirov region should be given to promoting Kirov tourist product, and namely, it is the brand creation and promotion.

The methodology for developing the regional strategy for promoting the domestic tourism object provides for an analysis of the main development scenarios, on the basis of which it's possible to make a choice regarding a specific option. The main development scenarios are:

- 'no change' scenario or it is called passive, not project. It is characterized by the absence of specific changes, the preservation of the existing structure, paces of growth and the minimum level of state support;

- innovative scenario or it is called active. It involves state participation and it relies on the significant use of potential resources, while significant changes are achieved and they ensure a noticeable increase in final results.

In our opinion the strategic development of the Kirov region tourist industry according to the 'no change' scenario is considered impossible, since it does not ensure the achievement of the set goal, which finally results in a sharp underrun in the tourism industry in terms of average Russian pace.

The innovative scenario of strategic development of the tourism in Kirov region can have both maximum and minimum paces of growth. 
The maximum innovative scenario assumes full use of the regional potential, the optimization of the structure and the system of managing the tourism industry, the infrastructure development, etc. In this case, the development rates of the regional tourist sector can be maximal, i.e. they correspond to the average annual rate of the Russian Federation and they account for 13-15\%. As a result, it will be possible to double the tourist flow, income and employment of the population for 5 years. Thus, Kirov region will be able to enter the group of the top ten leaders in tourism among Russian regions.

However, a minimal variant of the innovative development scenario is also possible. In this case the rate of tourism development will be lower than the average rates in Russia, i.e. they can be $8-11 \%$.

Unfortunately, the maximum innovative scenario isn't often realized because of the risks which are caused by the existing shortage of highly skilled personnel, low control, low investment attractiveness of the regional tourist industry. But on the other hand, the refusal of the possible leadership in the tourism sphere of Kirov region among the regions of Volga Federal District is also unacceptable.

Taking into account the analysis of available resources and the possibilities of their use, we consider that the optimal scenario of development is the one, which uses the strengths of both scenarios. As an optimal variant of the scenario, we propose a two-stage mixed scenario. At the first stage, a minimum version of the innovative scenario with a development rate of $11 \%$ should be implemented. This process implies implementing priority measures to improve the efficiency of using the tourist existing resources of the infrastructure: the creation of an effective management system, the implementation of professional marketing research, and the implementation of active promotion programs for regional tourist products. Moreover it includes conducting targeted retraining of personnel, working out the principles and mechanisms of state support and increasing investment attractiveness. The establishment of a monitoring system, management accounting and statistics, implementation of investment projects is also provided [16, 17].

At the second stage, it is assumed to correct the strategic development scenario of the tourist industry in order to increase the paces of growth and to evaluate the potential opportunities for entering the group of leaders among the regions in Volga Federal District.

Thus, in order to develop and to implement the development strategy of Kirov region as an object of domestic tourism, it is necessary to solve financial support problems. The financial support should not come only from all levels budgets, but also it's necessary to attract outside investments, taking into account the existing recreational potential, identifying problems of functioning and influencing factors $[18,19]$.

\section{Conclusion}

Developing the territory's touristic potential and investment attractiveness, as an object of domestic tourism, should be carried out within the framework of the adopted Development Strategy of the region. The formation of the territory's touristic and investment potential is influenced by such factors as: the territory`s image, the popularity of sights, the status of the events held, and the infrastructure development.

The financial support of developing the territory`s touristic potential is carried out mainly using the federal and regional budget funds. At the same time, the share of funds allocated from the Kirov region budget is almost 59\%. The share of attracted private investments is rather small, which is due to economic problems in the operative business of potential investors and a decline in most sectors of the country's economy.

The choice of a 'no change' scenario or an innovative scenario for developing a specific region while developing a regional strategy for promoting the territory as an object of domestic tourism, and the determination of the financial sources for realizing this strategy 
will depend on the quantity and quality of the fixed and variable factors of the territory`s investment and touristic potential.

\section{References}

1. I. Kulgachev , A. Nizovtseva, Young scientist, 6 , 477-483 ( 2016)

2. N. Zubarevich, S. Safronov, Social sciences and modernity, 6 (2013)

3. A. Jarimov, R. Popov, The bulletin of the Adyghe State University. Series 5: The Economy, 1 (138), 73-80 (2014)

4. V. Leksin, Regional Research of Russia, 2 (V. 5), 97-108, (2015)

5. A. Livshits, Social security issues, 7, 32 (2010)

6. T. Peters, R.Kh. Waterman, In search of perfection, the lessons of America's most successful companies (Moscow, 2010)

7. V. Afanasyev, E.V. Voronov, The bulletin of the Orenburg State University, 8, 21-28 (2005)

8. A. Boyko, Economic analysis: theory and practice, 12 (363), 2-9 (2014)

9. A. Gaponenko, Administrative Sciences, 2, 85-90, (2012)

10. S. Glazyev, Financial analytics: problems and solutions, 3, 2-10, (2008)

11. A. Gaponenko, Yu. S. Dulshchikova, Regional economy and management, M., (2006).

12. L. V. Nikolova, D.G. Rodionov, M.A. Bahauovna, International Journal of Economics and Financial Issues, 6(2), pp. 246-252 (2016)

13. A. Gukova, Financial analytics: problems and solutions, 1, 21-25, (2010)

14. N. Egorova, E. A. Kotlyar, Economic Science of Modern Russia, 3, 69-79 (2006)

15. A. Novoselov, The bulletin of the Siberian University of Consumer Cooperatives, $\mathbf{1}$, 45-52 (2011)

16. A. Mottaeva, IOP Conference Series: Earth and Environmental Science, 90(1), 012124 (2017)

17. E. Vasilyeva, I. Polyakova, MATEC Web of Conferences, 106, 08097 (2017)

18. M. A. Bahauovna, M. A. Bahauovna, International Journal of Applied Engineering Research, 10 (23), 43446-43449 (2015)

19. M. A. Bahauovna, M. A. Bahauovna, International Journal of Applied Engineering Research, 11 (9), 6808-6816 (2016) 